\title{
SYMBIOTIC NITROGEN-FIXING ABILITY OF CHICKPEA AND PRODUCTIVITY OF CROP AT DIFFERENT FERTILIZATION
}

\author{
H. M. Hospodarenko, I. V. Prokopchuk, S. V. Prokopchuk \\ Uman National University of Horticulture, Uman, Ukraine; e-mail: pivotbi@ukr.net
}

Results of studying effect of mineral fertilizers in combination with inoculation with nitrogen-fixing bacteria on chickpea productivity in podzolic black soil of Right-Bank Forest-Steppe of Ukraine have been shown. Pre-sowing bacterization contributed to the active formation and functioning of the symbiosis, provided that the background of nitrogen fertilizers did not exceed $60 \mathrm{~kg} / \mathrm{ha}$. Under the influence of mineral fertilizers both separately and in combination with seed inoculation, chickpea yield increased by 10.8-15.2 hwt/ha compared to the variant without fertilizers and without inoculation.

It was established that in order to obtain high and stable yields of chickpea seed in podzolic black soil of Right-Bank Forest-Steppe of Ukraine with low content of nitrogen of alkalihydrolyzing compounds and high content of mobile phosphorus and potassium, its fertilization system should include application of phosphate and potash fertilizers in the dose of $60 \mathrm{~kg} / \mathrm{ha}$ during primary tillage, and nitrogen fertilizers - for presowing cultivation. Before sowing, seeds should be processed with the suspension of ammonium molybdate and Ryzobofit.

Key words: nitrogen-fixing bacteria, chickpea, podzolic black soil, mineral fertilizers, productivity.

At the modern stage of development of agrarian manufacture, obtaining of qualitative crop production with the minimum application of synthetic preparations and the accumulation of nutrient elements in the soil, primarily nitrogen-containing organic compounds, are of great importance. Therefore, the substantiation of ways to increase the productivity of symbiotic nitrogen fixation and income of biological nitrogen to a plant is topical $[1 ; 2]$.

Symbiotic nitrogen fixation has a leading role in providing agrocenoses with biological nitrogen. Expansion of its scale will allow to improve soil fertility, reduce energy costs in agriculture and reduce the technogenic burden on the environment $[3,4]$.

Ukrainian soils have no native chick-pea rhizobia, and plants usually do not form nitrogen-fixing nodules, forming a crop due to autotrophic nutrition with nitrogen from mineral compounds of soil and fertilizers. Sometimes plants form single large nodules due to bacteria that are deposited with seeds. To increase the productivity of the crop and soil fertility due to the nitrogen fixation, chick-pea seed should be treated with the biopreparations of breeding highly effective strains before the sowing [5]. 
The development of nitrogen-fixing bacteria in the root systems of legumes is stimulated by molybdenum, which increases their productivity by 15-35\% depending on the soil-climatic conditions [6].

The inoculation of leguminous seeds reduces the need for nitrogen fertilizer application. Due to this, nitrogen nutrition improves and the immunity of plants to a number of fungal diseases increases [7]. The productivity of nitrogen fixation in agrocenoses with chick-pea is about $100-120 \mathrm{~kg} / \mathrm{ha}$ [8; 9].

The introduction of nitrogen fertilizers reduces the effectiveness of symbiosis, reduces the amount of nitrogen fixing nodules and their mass [10]. At the same time, one of the main factors providing stable nutrition of plants and improving the agrochemical parameters of soil in agrocenoses is a rational fertilizer system. To form a high chick-pea crop, plants must be provided with a balanced composition of nutrients in all phases of development, especially in critical periods [11]. In this regard, the objective of the study was to determine the effect of increasing doses of nitrogen fertilizers on the nitrogen-fixing capacity and productivity of chick-pea on a podzolic black soil of the Right-bank Forest-steppe of Ukraine, which seeds were inoculated with nitrogen-fixing bacteria.

Materials and methods. The study was conducted during 2011-2013 at the experimental field of the educational and research department of Uman National Horticultural University. The soil of the experimental area - podzolic hard clay-loam black soil on the loess. In the layer of 0-20 cm, it has an increased content of humus (3.4\%), mobile phosphorus compounds (131 mg/kg), and potassium $(113 \mathrm{mg} / \mathrm{kg})$, low nitrogen content of alkali hydrolyzed compounds $(108 \mathrm{mg} / \mathrm{kg})$, sulphur mobile compounds $(8.7 \mathrm{mg} / \mathrm{kg})$, and molybdenum $(0.15 \mathrm{mg} / \mathrm{kg})$, reaction of a soil solution is weakly acidic (pHsol 5.4) (definition according to DSTU 4362: 2004).

In the experiment, Rozanna variety of chick-pea was cultivated. The area of the experimental area was $54 \mathrm{~m}^{2}$, the accounting are $-30 \mathrm{~m}^{2}$, the repetition of the experiment is three times with the randomised placement of variants. The technology of chick-pea growth in the experiment corresponded to the standard for the Forest-steppe of Ukraine. The predecessor is winter wheat.

Fertilizers in the experiment were used as ammonium nitrate, carbamide, ammonium sulfate, double phosphate, potassium chloride, and ammonium molybdate. A two-year-old defecate with a $\mathrm{CaCO}_{3}$ content of $70 \%$ was used as the calcitic material; the dose of which was calculated by hydrolytic acidity. The effect and interaction of two factors has been studied: A - fertilization, B - Inoculation. Phosphate, potassium fertilizers and defecate were applied under fall plowing, nitrogen fertilizers - under pre-sowing cultivation and in a foliar manner - during the phase of chick-pea beans formation as $20 \%$ carbamide solution. Treatment of seeds by Ryzobofit suspension (based on the Mesorhizobium cicerii H-12) calculated as $10^{6}$ bacteria per seed was carried out two hours before sowing.

The number and mass of nodular formations on the root system were determined by the method of H. S. Posypanov [12]; symbiotic nitrogen fixation was calculated on the basis of the accumulation of 
nitrogen by the mass of inoculated chick-pea plants. [13] Statistical analysis of the data was carried out by the analysis of variance method [14].

Results and discussion. It was established that the formation of nodules on the roots of chick-pea plans significantly depended on nitrogen supply, as well as on the use of a bacterial preparation (Table 1).

Determination of the total number and mass of nodules gives an opportunity to evaluate the potential of the symbiotic nitrogen fixation in plants. In the flowering phase, in variants with inoculation, a significant increase in the number of formed tubers on the roots of chick-pea plants was observed. The greatest number of them was formed in variants using Ryzobofit, in particular in the phosphoricpotassium background with starting doses of nitrogen fertilizers and liming of the soil.

Table 1. Influence of mineral fertilizers and inoculation on formation of symbiotic parameters of chickpea in the flowering phase, 2011-2013 pp.

\begin{tabular}{|l|c|c|c|c|}
\hline \multirow{2}{*}{\multicolumn{1}{c}{ Variants of experiment }} & \multicolumn{2}{c|}{$\begin{array}{c}\text { Number of nodules, } \\
\text { U/plant }\end{array}$} & \multicolumn{2}{c|}{$\begin{array}{c}\text { Weigh of nodules, } \\
\text { g/plant }\end{array}$} \\
\cline { 2 - 5 } & 1 & 2 & 1 & 2 \\
\hline Control, without fertilizers & 3 & 6 & 0,07 & 0,18 \\
\hline $\mathrm{N}_{60} \mathrm{~K}_{60}$ & 3 & 8 & 0,06 & 0,20 \\
\hline $\mathrm{N}_{60} \mathrm{P}_{60}$ & 3 & 9 & 0,07 & 0,21 \\
\hline $\mathrm{P}_{60} \mathrm{~K}_{60}-$ background & 3 & 8 & 0,09 & 0,22 \\
\hline background $+\mathrm{N}_{30}$ & 3 & 10 & 0,07 & 0,25 \\
\hline background $+\mathrm{N}_{30} \mathrm{~S}_{35}$ & 4 & 11 & 0,09 & 0,25 \\
\hline background $+\mathrm{N}_{60}$ & 4 & 10 & 0,09 & 0,24 \\
\hline background $+\mathrm{N}_{90}$ & 3 & 8 & 0,08 & 0,24 \\
\hline background + Mo $+\mathrm{N}_{30}$ & 4 & 13 & 0,08 & 0,30 \\
\hline $\mathrm{CaCO}_{3}+$ background $+\mathrm{N}_{30}$ & 4 & 15 & 0,08 & 0,32 \\
\hline $\mathrm{CaCO}_{3}+$ background $+\mathrm{Mo}+\mathrm{N}_{30}$ & 4 & 16 & 0,08 & 0,33 \\
\hline $\mathrm{CaCO}_{3}+$ background $+\mathrm{Mo}+\mathrm{N}_{30}+\mathrm{N}_{30}$ & 3 & 16 & 0,07 & 0,35 \\
\hline
\end{tabular}

Note. 1 - without bacterization; 2 - bacterization.

In variants with inoculation of seeds on phosphate-potassium background, the number of nodules increased by 5 units/plant, and their weight by $0.15 \mathrm{~g}$ compared to the control variant. The introduction of nitrogen fertilizers in the phosphorus-potassium background at a dose of $60 \mathrm{~kg} / \mathrm{ha}$ per year, exceeding compared with control was 7 units/plant and by the weight of the nodules $-0.17 \mathrm{~g}$, respectively.

The introduction of the maximum dose of mineral fertilizers $\mathrm{P}_{60} \mathrm{~K}_{60}+\mathrm{N}_{90}$ led to a decrease in the nodule formation activity. At the same time, the weight of the nodules was equal to the variant with $\mathrm{P}_{60} \mathrm{~K}_{60}+\mathrm{N}_{60}$. Under the introduction of starting doses of nitrogen (30 kg/ha of active ingredient), phosphoric and potash fertilizers (60 kg/ha of active ingredient), molybdate ammonium and soil 
calcification, the number of nodules increased by 13 units/plant, and their mass increased by $0.28 \mathrm{~g}$ compared to the control variant (without inoculation).

As for the inoculation of chick-pea seeds, this agro-measure was very effective. It contributed to an increase in the number of nodules and their mass in all variants of the experiment compared to the control variant. Mineral fertilizers to a lesser extent influenced the formation of nodules and their mass, in comparison with inoculation and their combined use, but among types of fertilizers it is necessary to note the positive effects of nitrogen fertilizers, provided that their dose should not exceed $60 \mathrm{~kg} / \mathrm{ha}$ of active ingredient.

In order to take into account the role of culture as a nitrogen storage medium in soil, it is important to measure its content in the root plant remnants. Analyzing the data in the Table 2, it should be noted that the highest proportion of nitrogen in the root remnants (from its total content in biomass of plants) is noted in the variant without the introduction of mineral fertilizers $-77.7 \mathrm{~kg} / \mathrm{ha}$ or $43 \%$. Under the introduction of phosphorus and potassium fertilizers only, the accumulation of nitrogen in the root remnants was $74.0 \mathrm{~kg} / \mathrm{ha}$, and the share of total content in biomass decreased by $6 \%$ compared with control.

Table 2. Influence of fertilization and inoculation on accumulation of nitrogen in the root remnants of chickpea in the soil layer 0-40 cm (2011-2013)

\begin{tabular}{|c|c|c|c|c|}
\hline \multirow[t]{2}{*}{ Variants of experiment } & \multicolumn{2}{|c|}{$\begin{array}{l}\text { Nitrogen in the root remnants, } \\
\qquad \mathrm{kg} / \mathrm{ha}\end{array}$} & \multicolumn{2}{|c|}{$\begin{array}{l}\text { Share of Nitrogen in the } \\
\text { root remnants from total } \\
\text { content in biomass, } \%\end{array}$} \\
\hline & $\begin{array}{c}\text { without } \\
\text { bacterization }\end{array}$ & bacterization & $\begin{array}{c}\text { without } \\
\text { bacterization }\end{array}$ & bacterization \\
\hline Control, without fertilizers & 77,7 & 102,7 & 43 & 45 \\
\hline $\mathrm{N}_{60} \mathrm{~K}_{60}$ & 74,1 & 106,4 & 33 & 37 \\
\hline $\mathrm{N}_{60} \mathrm{P}_{60}$ & 76,5 & 113,7 & 32 & 37 \\
\hline $\mathrm{P}_{60} \mathrm{~K}_{60}$ - background & 74,0 & 104,7 & 37 & 41 \\
\hline background $+\mathrm{N}_{30}$ & 75,8 & 103,9 & 33 & 36 \\
\hline background $+\mathrm{N}_{30} \mathrm{~S}_{35}$ & 78,4 & 118,7 & 32 & 37 \\
\hline background $+\mathrm{N}_{60}$ & 73,6 & 105,7 & 30 & 34 \\
\hline background $+\mathrm{N}_{90}$ & 77,1 & 113,8 & 30 & 36 \\
\hline background $+\mathrm{Mo}+\mathrm{N}_{30}$ & 73,4 & 110,4 & 30 & 35 \\
\hline $\mathrm{CaCO}_{3}+$ background $+\mathrm{N}_{30}$ & 75,0 & 113,9 & 29 & 34 \\
\hline $\mathrm{CaCO}_{3}+$ background $+\mathrm{Mo}+\mathrm{N}_{30}$ & 75,1 & 114,4 & 29 & 34 \\
\hline $\mathrm{CaCO}_{3}+$ background $+\mathrm{Mo}+\mathrm{N}_{30}+\mathrm{N}_{30}$ & 79,6 & 104,3 & 29 & 31 \\
\hline
\end{tabular}


Improvement of the mineral nutrition conditions due to the application of starting doses of nitrogen fertilizers (30 kg/ha of active ingredient) did not affect the accumulation of nitrogen in the root remnants compared with the control. Under the dose of nitrogen fertilizers of $60-90 \mathrm{~kg} / \mathrm{ha}$, the root remnants accumulates $73.6-77.1 \mathrm{~kg} / \mathrm{ha}$ of nitrogen, and its share from the total content in the biomass of chick-pea plants was by $13 \%$ lower compared with the control variant.

The highest accumulation of nitrogen in the root remnants was noted in the variations of the experiment: background $+\mathrm{N}_{30} \mathrm{~S}_{35}(78.4 \mathrm{~kg} / \mathrm{ha})$ and $\mathrm{CaCO}_{3}+$ background $+\mathrm{Mo}+\mathrm{N}_{30}+\mathrm{N}_{30}(79.6 \mathrm{~kg} / \mathrm{ha})$, respectively, and its share was 32 and $29 \%$ of total content in biomass.

The inoculation of seeds by nitrogen-fixing bacteria and the combination with the studied doses of mineral fertilizers contributed to an increase in the accumulation of nitrogen in the root remnants of chick-pea plants. In the variant with inoculation of seeds only, this indicator increased by $26.0 \mathrm{~kg} / \mathrm{ha}$, and its share was $2 \%$ higher compared with the control variant. The smallest amount of accumulated nitrogen was found in the variant with the introduction of the starting dose of nitrogen fertilizers $(30 \mathrm{~kg} / \mathrm{ha}$ of active ingredient) on the phosphorus-potassium background $-25.6 \mathrm{~kg} / \mathrm{ha}$, and its share in the total rendering decreased up to $36 \%$ (by the indicator in control $45 \%$ ).

In variants with liming of soil, following introduction of phosphoric and potassium and starting doses of nitrogen (30 kg/ha of active ingredient) and ammonium molybdate, the root system of chick-pea plants accumulated from 104.3 to $114.4 \mathrm{~kg} / \mathrm{ha}$ of nitrogen with a share of $31-34 \%$ of total content in biomass.

Consequently, with an increase in the dose of mineral fertilizers and the inoculation of seeds, the share of accumulated nitrogen in the root remnants of chick-pea plants decreases.

It was established that mineral fertilizers, as well as inoculation, contributed to the better formation of chick-pea grain. As seen from the data in Table 3, on average, over the years of study in the variant without fertilizer, the yield was $21.5 \mathrm{hwt} / \mathrm{ha}$, and under the introduction of $\mathrm{P}_{60} \mathrm{~K}_{60}$ increased by $2.7 \mathrm{hwt} / \mathrm{ha}$. Under the use of nitrogen fertilizers at a dose of $30-90 \mathrm{~kg} / \mathrm{ha}$ of fertilizer, it increased by 5.8 $9.2 \mathrm{hwt} / \mathrm{ha}$ compared with control. The highest yield was in variants with the introduction of starting doses of nitrogen fertilizers and ammonium molybdate at the phosphorus-potassium background with liming of the soil - without inoculation $32.3 \mathrm{hwt} / \mathrm{ha}$, and with its implementation - by $4.4 \mathrm{hwt} / \mathrm{ha}$ higher.

Conducting pre-sowing inoculation contributed to an increase in yields of $2.8 \mathrm{hwt} / \mathrm{ha}$ in the control variant without fertilizers. Under the combination of mineral fertilizers with inoculation, yields increased by 6.0 to $15.2 \mathrm{hwt} / \mathrm{ha}$, depending on the experimental variants. 
Table 3. Yield of grain of chickpea depending on mineral fertilization and inoculation, $h w t / h a$

\begin{tabular}{|c|c|c|c|c|c|c|c|c|c|}
\hline \multirow{2}{*}{\multicolumn{2}{|c|}{$\begin{array}{c}\text { Variants of experiment } \\
\text { (factor A) }\end{array}$}} & \multicolumn{4}{|c|}{ without bacterization } & \multicolumn{4}{|c|}{$\begin{array}{c}\text { bacterization } \\
\text { (factor B) }\end{array}$} \\
\hline & & $2011 \mathrm{p}$ & 2012 p. & $2013 \mathrm{p}$. & середнє & 2011 p. & 2012 p. & 2013 p. & середнє \\
\hline \multicolumn{2}{|c|}{$\begin{array}{l}\text { Control, without } \\
\text { fertilizers }\end{array}$} & 21,7 & 20,1 & 22,7 & 21,5 & 25,2 & 22,9 & 24,8 & 24,3 \\
\hline \multicolumn{2}{|l|}{$\mathrm{N}_{60} \mathrm{~K}_{60}$} & 27,0 & 23,5 & 27,9 & 26,1 & 32,3 & 27,9 & 29,8 & 30,0 \\
\hline \multicolumn{2}{|l|}{$\mathrm{N}_{60} \mathrm{P}_{60}$} & 28,5 & 25,0 & 30,9 & 28,1 & 34,1 & 29,9 & 32,9 & 32,3 \\
\hline \multicolumn{2}{|c|}{$\mathrm{P}_{60} \mathrm{~K}_{60}-$ background } & 24,4 & 21,7 & 26,4 & 24,2 & 28,7 & 25,8 & 28,1 & 27,5 \\
\hline \multicolumn{2}{|c|}{ background $+\mathrm{N}_{30}$} & 27,5 & 24,6 & 30,5 & 27,5 & 33,1 & 29,6 & 31,9 & 31,5 \\
\hline \multicolumn{2}{|c|}{ background $+\mathrm{N}_{30} \mathrm{~S}_{35}$} & 29,2 & 25,6 & 31,5 & 28,8 & 35,9 & 31,5 & 33,5 & 33,6 \\
\hline \multicolumn{2}{|c|}{ background $+\mathrm{N}_{60}$} & 29,3 & 26,5 & 32,9 & 29,6 & 35,1 & 31,3 & 35,5 & 34,0 \\
\hline \multicolumn{2}{|c|}{ background $+\mathrm{N}_{90}$} & 30,9 & 27,5 & 33,9 & 30,8 & 35,6 & 31,7 & 34,6 & 34,0 \\
\hline \multicolumn{2}{|c|}{$\begin{array}{l}\text { background }+\mathrm{Mo}+\mathrm{N} \\
30\end{array}$} & 29,7 & 26,6 & 31,5 & 29,3 & 35,7 & 32,0 & 34,0 & 33,9 \\
\hline \multicolumn{2}{|c|}{$\begin{array}{l}\mathrm{CaCO}_{3}+\text { background } \\
+\mathrm{N}_{30}\end{array}$} & 30,1 & 27,5 & 34,9 & 30,8 & 37,1 & 32,0 & 37,6 & 35,6 \\
\hline \multicolumn{2}{|c|}{$\begin{array}{l}\mathrm{CaCO}_{3}+\text { background } \\
+\mathrm{Mo}+\mathrm{N}_{30}\end{array}$} & 30,4 & 27,4 & 35,2 & 31,0 & 37,5 & 32,4 & 38,0 & 36,0 \\
\hline \multicolumn{2}{|c|}{$\begin{array}{l}\mathrm{CaCO}_{3}+\text { background } \\
+\mathrm{Mo}+\mathrm{N}_{30}+\mathrm{N}_{30}\end{array}$} & 31,8 & 28,4 & 36,7 & 32,3 & 38,0 & 32,6 & 39,5 & 36,7 \\
\hline \multirow{3}{*}{$L S D_{05}$} & 2011 & \multicolumn{8}{|c|}{ Factor $A-0,7 ; B-0,3 ; A B-1,0$} \\
\hline & 2012 & \multicolumn{8}{|c|}{ Factor $A-1,1 ; B-0,4 ; A B-1,5$} \\
\hline & 2013 & \multicolumn{8}{|c|}{ Factor $A-0,9 ; B-0,4 ; A B-1,3$} \\
\hline
\end{tabular}

Studies have shown that the combination of pre-sowing inoculation of seeds and various doses of mineral fertilizers, yield increment from inoculation decreased with increasing nitrogen fertilizer doses. Thus, in the variants: background $+\mathrm{N}_{30}$ and background $+\mathrm{N}_{60}$, the increment from Ryzobofit inoculation was $15 \%$, whereas in the variant: background $+\mathrm{N}_{90}$ it was $10 \%$ only. In variants with introduction of starting doses of nitrogen fertilizers and ammonium molybdate at the phosphorus-potassium background with soil liming $\left(\mathrm{CaCO}_{3}+\right.$ background $+\mathrm{N}_{30}, \mathrm{CaCO}_{3}+$ background $+\mathrm{Mo}+\mathrm{N}_{30}, \mathrm{CaCO}_{3}+$ background + Mo $+\mathrm{N}_{30}+\mathrm{N}_{30}$ ), it comprised 15, 16 and $14 \%$ compared with control, respectively. The largest increment in yield was obtained under the use of nitrogen-fixing bacteria in the variant: background + $\mathrm{N}_{30} \mathrm{~S}_{35}-17 \%$. 
1. Розвадовський А. М. Інтенсивна технологія вирощування овочевого гороху / Розвадовський А. М. - К. : Урожай, 2000. - 40 с.

2. Ушкаренко В. О. Зрошуване землеробство / Ушкаренко В. О. - К. : Урожай, 1994. - 325 с.

3. Комок М. С. Ефективність симбіозу бульбочкових бактерій з рослинами сої в залежності від виду біопрепарату / М. С. Комок, В. В. Волкогон, Л. В. Косенко // Сільськогосподарська мікробіологія. - 2010. - Вип. 11. - С. 7-19.

4. Нагорний В. І. Агротехнічне значення та роль сої в екологізації сільськогосподарського виробництва / В. І. Нагорний, Ю. А. Романько // Вісник Сумського НАУ. — 2009. - Вип. 11 (18). - C. 79-83.

5. Бушулян О. В. Рекомендації з вирощування нуту в південному Степу України / О. В. Бушулян // Посібник Українського хлібороба. Науково-практичний щорічник. - К., 2012. — Том. 2. C. 304-307.

6. Бабич А. О. Зернобобовые культуры / Бабич А. О. - К. : Урожай, 1984. — 96 с.

7. Господаренко Г. Особливості удобрення зернобобових / Господаренко Г. - The Ukrainian Farmer. - 2013. - № 2. - C. 66-68.

8. Січкар В. Технологія вирощування нуту в Україні / В. Січкар, О. Бушулян // Пропозиція. 2001. — № 10. - C. 42-43.

9. Патыка В.Ф. Эфективность применения ризоторфина и азотных удобрений под сою на орошаемых землях юга Украины / В. Ф. Патыка // Агрохимия. - 1987. - № 12. - С. 37.

10. Дробышева Н. И. Влияние удобрений на образование клубеньков и урожай сои / Н. И. Дробышева // Агрохимия. - 2000. - № 2. - С. 59-61.

11. Михайлов В.Г. Реакція сортів і селекційних номерів сої на зміну умов середовища / В. Г. Михайлов, О. 3. Щербина, Л. С. Романяк // Корми і кормовиробництво. — 2001. — № 47. — C. 27-29.

12. Посыпанов Г. С. Методы изучения биологической фиксации азота воздуха / Посыпанов Г. С. - М. : Агропромиздат, 1991. - 299 с.

13. Пат. 2195104 Российская Федерация, A01G7/00. Способ оценки азотфиксирующей способности бобовых культур / Сидорова К. К., Назарюк В. М., Кленова М. И.; заявители патентообладатели Институт цитологи и генетики СО РАН, Институт почвоведения и агрохимии СО РАН. - № 2001109176/13; заявл. 05.04.2001; опубл. 27.12.2002.

14. Дисперсійний і кореляційний аналіз у землеробстві та рослинництві: навчальний посібник / [В. О. Ушкаренко, В. Л. Нікішенко, С. П. Голобородько, С. В. Коковіхін]. - Херсон : Айлант, 2008. $-272 \mathrm{c}$. 


\section{СИМБИОТИЧЕСКАЯ \\ АЗОТФИКСИРУЮЩАЯ СПОСОБНОСТЬ НУТА И ПРОДУКТИВНОСТЬ КУЛЬТУРЫ ПРИ РАЗНОМ УДОБРЕНИИ}

\author{
Г. Н. Господаренко, И. В. Прокопчук, \\ С. В. Прокопчук \\ Уманский национальный университет \\ садоводства, г. Умань
}

Приведень результатьи исследований влияния минеральных удобрений в сочетании с инокуляиией азотфиксирующими бактериями на продуктивность нута на черноземе оподзоленном Правобережной Лесостепи Украины. Предпосевная бактеризация способствовала активному формированию $u$ функиионированию симбиотического аппарата при условии, что фон азотных удобрений не превышал 60 кг/га.

Под действием минеральных удобрений как отдельно, так и в сочетании с инокуляции семян урожайность нута повышалась на 10,815,2 u/га по сравнению с вариантом без удобрений и без инокулящии.

Установлено, что для получения высоких и стабильных урожаев зерна нута на черноземе оподзоленном Правобережной Лесостепи Украины с низким содержанием азота щеёлочногидролизованых соединений $u$ повышенным содержанием подвижных фосфора и калия, система его удобрения должна предусматривать применение фосфорных и калийных удобрений в дозе 60 кг/га д. в. под основную обработку почвы, а азотных - под предпосевную культивацию. Семена перед посевом следует обрабатывать суспензией молибдата аммония и Ризобофита.

Ключевые слова: азотфиксирующие бактерии, нут, чернозем оподзоленный, минеральные удобрения, урожайность.

\section{СИМБІОТИЧНА}

\section{АЗОТФІКСУВАЛЬНА ЗДАТНІСТЬ НУТУ ТА ПРОДУКТИВНІСТЬ КУЛЬТУРИ ЗА РІЗНОГО УДОБРЕННЯ}

\author{
Г. М. Господаренко, І. В. Прокопчук, \\ С. В. Прокопчук \\ Уманський національний університет \\ садівництва, м. Умань
}

Наведено результати досліджень впливу мінеральних добрив у поєднанні з інокулячією азотфіксувальними бактеріями на симбіотичну азотфіксувальну здатність та продуктивність нуту на чорноземі опідзоленому Правобережного Лісостепу України. Передпосівна бактеризачія сприяла активному формуванню $i$ функціонуванню симбіотичного апарату за умови, щзо фон азотних добрив не перевищував 60 кг/га. $3 а$ діі мінеральних добрив як окремо, так $i$ в поєднанні з інокулячією насіння врожайність нуту підвищувалася на 10,8-15,2 u/га порівняно з варіантом без добрив $i$ без інокуляції.

Встановлено, щуо для отримання високих i стабільних урожаїв зерна нуту на чорноземі опідзоленому Правобережного Лісостепу України з низьким вмістом азоту лужногідролізованих сполук $i$ підвищеним вмістом рухомих сполук фосфору та калію, система його удобрення повинна передбачати застосування фосфорних $і$ калійних добрив у дозі по 60 кг/га д. p. під основний обробіток трунту, а азотних - під передпосівну культивачію. Насіння перед сівбою слід обробляти суспензією молібдату амонію та Ризобофіту.

Ключові слова: азотфіксувальні бактерії, нут, чорнозем опідзолений, мінеральні добрива, врожайність. 